\title{
STAR MARKETER'S IMPACT ON THE MARKET STRATEGY CHOICE
}

\author{
Goran Vlašić, ${ }^{*}$ Joe Hair, ${ }^{* *}$ Zoran Krupka ${ }^{* * *}$
}

Received: 11.9. 2017

Accepted: 5. 12. 2017

Original scientific paper

UDC 658.8:659.1-051

\begin{abstract}
We focus on understanding the role of star marketers in pursuing a market-driven vs. a market-driving strategy. Results indicate that market-driving and market-driven strategies are two approaches that can be pursued by marketoriented firms. A star marketer has a robust positive influence on market-driving strategy. In con-
\end{abstract}

\section{INTRODUCTION}

Recognizing a significant heterogeneity in human capital, especially in the ability to generate innovative outputs, research on innovation has introduced the concept of star scientists (Lotka, 1926; Ernst, Laptien, \& Vitt, 2000; Felin \& Hesterly, 2007; Rothaermel \& Hess, 2007). Star scientists tend to deliver more/better innovative outputs since they are able to effectively "gather and understand external information and then translate and disseminate this information into terms that are meaningful and useful to other organization members." (Rothaer- trast, a star marketer has no meaningful influence on market-driven strategy. In short, while star marketers are very important for market-driving strategy and long term success, they represent an unnecessary cost and provide no added value to companies focusing on market-driven strategies and short term results.

Keywords: market-driving strategy, marketdriven strategy, star marketer, market orientation

mel \& Hess, 2007, p. 900). In addition, they represent an organization's information and knowledge core, ultimately changing cultural and behavioral norms, legitimizing a stronger focus on basic research, and changing the strategic direction of the firm (Rothaermel \& Hess, 2007).

As they have such an influential role in innovation, we propose the concept of star marketers, defined as highly experienced and educated, as well as well-recognized marketing experts, that have an important role in the firm's choice of market strategies. While market-driven strategies imply a sim-

* Goran Vlašić, PhD, Assistant Professor, Faculty of Economics and Business - University of Zagreb, Trg J. F. Kennedyja 6, 10000 Zagreb, Croatia, E-mail: gvlasic@efzg.hr

** Joe Hair, PhD, Cleverdon Chair of Business, Mitchell College of Business - University of South Alabama, 5811 USA Drive South, Mobile, AL 36688, USA, E-mail: jhair@southalabama.edu

*** Zoran Krupka, PhD, Associate Professor, Faculty of Economics and Business - University of Zagreb, Trg J. F. Kennedyja 6, 10000 Zagreb, Croatia, E-mail: zkrupka@efzg.hr 
pler market approach by which marketing responds to markets, a market-driving strategy requires companies to actively shape their markets. Thus, while market-driven strategy can be pursued by any market-oriented organization, market-driving strategy requires daring and capable individuals devising and executing market strategies. Therefore, in this research we focus on uncovering the role of star marketers in the choice of market-driven vs. market-driving strategy.

Market-driven strategies focus on understanding consumer needs and catering to their preferences. Such companies are customer-centric as they are quick to respond to consumers' expectations. On the other hand, market-driving strategies encompass companies' activities to actively manage consumer preferences (Carpenter \& Nakamoto, 1994) and shape markets in general (Jaworski, Kohli, \& Sahay, 2000). In this research we define market-driving strategy as the extent to which a firm invests resources (time, money, effort) in changing consumer preferences in a way that enhances the benefit the consumer perceives from the focal product. Generally, market driving can be achieved by: (a) changing the extent to which the consumer appreciates the attributes on which the focal product outperforms others, (b) changing the extent to which the consumer perceives the focal category as the one providing him/her with the ability to satisfy a certain need, and (c) changing consumer's motivation to satisfy a certain need that can be addressed by the focal product.

Market-driving strategy is important as it is the key for achieving first mover advantages (Carpenter \& Nakamoto, 1994), and enables the firm to benefit from competing on an alternative competitive landscape by managing consumer preferences rather than responding to them (Jaworski, Kohli, \& Sahay, 2000). Such strategies require inno- vative approaches to markets and are more uncertain, but provide rich platforms for growth (McDermott \& O'Connor, 2002). Although market-driving strategies are increasingly discussed, research is lacking on the contexts that favor such strategy. Since market-driving strategy is a market exploration strategy, it assumes learning and diverging from the existing market trajectory and dealing with risk (Levinthal \& March, 1993; Kumar, Scheer, \& Kotler, 2000). Thus, such strategy requires: (a) a broad knowledge set that enables the firm to look beyond existing consumers, enhancing its ability to conceptualize market driving strategy, and (b) willingness to accept risk, enhancing its readiness to accept and implement this daring strategy. This broad knowledge set enhances the potential to recombine knowledge elements to increase opportunity recognition and creative potential (Kogut \& Zander, 1992), enables connections of disparate information, ideas and concepts yielding broader and more insightful perspectives (Reed \& DeFillippi, 1990), enhances the probability of "happy accidents" (Prabhu, Chandy, \& Ellis, 2005) and generally benefits innovative activities (De Luca \& Atuahene-Gima, 2007). Another aspect we consider is the risk that is inherent in all innovative activities, arising primarily due to the uncertainty about the final payoffs of an innovative strategy (Leiponen \& Helfat, 2010). In general, firms primarily pursue more standard (i.e. less radical) projects that are characterized by lower risk and immediate rewards (Chandy \& Tellis, 1998; McDermott \& O'Connor, 2002).

Along with research on innovation, where star-scientists have been shown to have significant impact on companies' innovative endeavors, we focus on the star marketer, defined as highly experienced and educated well-recognized marketing expert. He/She is an important asset who can 
help envision and execute a more risky market-driving approach (by believing in his/ her abilities to pursue bold strategies). Star marketers have broad knowledge and competences required to devise and implement such a daring, unorthodox strategy. Thus, we are focused on understanding the role of star marketer beyond the characteristics of the marketing department in which they work.

We contribute to the literature by introducing the concept of the star marketer, drawn from innovation literature on star scientists. In addition, we test the role of the star marketer for market-driving vs. market-driven strategy, above and beyond market characteristics (within-category and cross-category competitive intensity), organizational characteristics (market orientation and technology orientation) and department characteristics (marketing department's capabilities and integration with marketing agency).

\section{MODEL AND VARIABLES}

We focus on two market characteristics that reflect the level of competition. Withincategory competitive intensity is defined as the degree of competition that a product faces within its category (Zhou, Yim, \& Tse, 2005). In such competitive environments, companies are expected to narrow their focus to quickly respond to market demands, i.e. consumer insights and competitors' actions. Exhausted by day-to-day competition, companies in such environments are less likely to consider a more demanding strategy of market driving, which would require them to look beyond immediate reactions and returns - in order to alter market structures and preferences for longer-term returns. In contrast, cross-category competitive intensity is defined as the extent to which different categories compete to become the best one for satisfying a particular need (following Zhou, Yim, \& Tse, 2005). It reflects the number of categories competing to be perceived as the one providing the consumer with the greatest ability to satisfy some focal need. Literature shows that categories within a given focal need can be substitutes, i.e. several categories can address the same need (Shocker, Bayus, \& Kim, 2004; Russell, et al., 1999) and compete with one another for consumers (Roberts \& Lattin, 1991). In such competitive environments, companies recognize that they need to look beyond markets, and thus are likely to focus less on market-driven and more on market-driving strategies - making them active shapers of markets in consumer minds.

We also include two firm-level control variables - which reflect the company's approach to markets as they build their strategies either starting from the consumer or from its products and internal efforts. Market orientation (Kohli \& Jaworski, 1990; Narver \& Slater, 1990) "is the central element of the management philosophy based on the marketing concept ... [and it is] presumed to contribute to long-term profitability" (Deshpandé \& Farley, 1999, p. 112). It can be defined from activities and cultural perspectives. From an activities perspective, market orientation is defined as "the organizationwide generation of market intelligence pertaining to current and future customer needs, dissemination of the intelligence across departments, and organizationwide responsiveness to it" (Kohli \& Jaworski, 1990). From a cultural perspective, dimensions of the market orientation construct include: customer orientation (the sufficient understanding of one's target to be able to create superior value for them continuously), competitor orientation (a seller understands the shortterm strengths and weaknesses and long-term capabilities and strategies of both the key 
current and the key potential competitors), and inter-functional coordination (the coordinated utilization of company resources in creating superior value for target customers) (Narver \& Slater, 1990). In response to criticism that market orientation impedes innovation and performance (Bennett \& Cooper, 1979; Christensen \& Bower, 1996; Heyes \& Abernathy, 1980), marketing literature has responded by stressing that market orientation helps companies to be both responsive and proactive (Narver, Slater, \& MacLachlan, 2004), as well as market-driven and market driving (Jaworski, Kohli, \& Sahay, 2000). On the other hand, technology orientation reflects the technology-push philosophy where a firm advocates a commitment to R\&D, the acquisition of new technologies, and the application of the latest technology (Narver, Slater, \& MacLachlan, 2004; Zhou, Yim, \& Tse, 2005; Gatignon \& Xuereb, 1997). Technology oriented firms focus on developing and implementing new technologies thus having no implications for the extent to which such companies would be market-driven or market-driving in their activities.

At the department level, we control for marketing departments' capabilities defined as the extent to which the marketing department is able to envision and achieve the desired position of its products in consumer minds. Highly capable marketing departments tend to be well aware of consumers' current cognitive structures and have a clear idea of consumers' perceptual maps. Thus, such departments are able to better recognize the "empty" position they could occupy and are better in achieving this particular position in consumer cognitive schema. While market-driven strategies are "easier" as they imply delivering on market expectations, market-driving strategies require a highly capable marketing department. Besides the marketing department's capabilities, marketing departments generally cooperate with marketing agencies to envision and deliver marketing results. Marketing department integration is defined as the extent to which the marketing department coordinates with other actors (Verhoef \& Leeflang, 2009; Guenzi \& Troilo, 2006). In our paper, we focus on the marketing department's integration with the marketing agency, which is an important actor specialized in managing market information and developing and executing marketing strategy, and has a broad experience set acquired by serving multiple companies from multiple industries (Soberman, 2009). Marketing agencies are exposed to a broader set of experiences and thus are likely to help marketing departments envision marketdriving strategies that can benefit from understanding markets across categories.

The focus of our research is on understanding how individuals in charge of marketing can influence firm's marketing activities, beyond what capable marketing departments, integrated with marketing agencies, can deliver, and beyond the value that organization-wide market orientation can provide. Therefore, we introduce the concept of star marketers to reflect significant heterogeneity in human capital, especially in case of ability to generate innovative outputs, dividing it into: stars and non-stars (Lotka, 1926; Ernst, Laptien, \& Vitt, 2000; Felin \& Hesterly, 2007; Rothaermel \& Hess, 2007). Stars assume gate-keeping and boundaryspanning roles that are key for innovative endeavors (Allen \& Cohen, 1969; Tushman, 1977; Rothaermel \& Hess, 2007). Star employees are often more intelligent and creative than an average employee and have better links to external sources of knowledge (Zucker, Darby, \& Brewer, 1998; Ernst, Laptien, \& Vitt, 2000; Amabile, Conti, Coon, Lazenby, \& Herron, 1996).

Such individuals not only are able to generate new knowledge, but are also better in gathering knowledge from diverse sources and translating it into usable information for 
the firm (Rothaermel \& Hess, 2007). These individuals primarily engage in exploration and, as they are confident in their position, often deviate from conventional behaviors and develop bold ideas (Zuckerman \& Phillips, 2001). They are more likely to pursue projects with greater risk and greater reward potential, and tend to be more productive and more influential (Zucker \& Darby, 1997). Such individuals tend to get more financial and top management support for their endeavors (Hargadon \& Sutton, 1997). Finally, they are better viewed as entrepreneurial individuals who value the pleasure, recognition, and resources that come from being the first to make a significant new change (Zucker \& Darby, 1998).

Although the research on star employees is primarily done in technology innovation, we argue that in marketing we can also distinguish marketing stars from non-stars (or "staff") employees. Since market-driving strategies require audacious employees who are able to envision and utilize new opportunities, we expect that star marketers are the key to devising market-driving strategies. In other words, we expect that star marketers are a valuable asset for companies, as these individuals are capable of steering the company into innovating and managing the markets, rather than merely responding to market conditions. Such individuals are able to envision opportunities that are not obvious to non-marketers and are more likely to get top management support for competing on managing consumer preferences. These individuals are exploration-oriented, seeking new opportunities. On the other hand, nonstar marketers are focused on exploitation, taking the context as given and adjusting to the market demands. These marketers are not likely to question the routinized market behaviors and will generally aim at minimizing risk: assessing consumer preferences and responding to them. Nonstar marketers are more likely to focus on executing the daily business, rather than devising bold strategic options. Thus, we hypothesize that:

$\mathrm{H}_{1}$ : Star marketers have a positive influence on market driving strategy.

$\mathrm{H}_{2}$ : Star marketers do not have an impact on market driven strategy.

\section{DATA COLLECTION}

The study consists of three stages. In the first stage, we conducted qualitative interviews with 26 marketing managers, CEOs or company owners in different industries and in two different contexts: a developing country and a developed country. The goal of these interviews was to arrive at a practitioners' market-driving strategy definition and develop possible items for measuring the construct. Interviews were followed with a pretest $(n=63$ managers in a developed and a developing country). Then we administered a large-scale webbased survey among marketing managers or others in charge of marketing activities (e.g. CEOs or owners in smaller firms). We used the AMADEUS database to obtain a list of eligible firms in one European country. From that list we contacted 1,573 companies by sending personalized personalized e-mails, soliciting participation in the study, with a link to the web survey.

We received a total of 315 responses (20.03\% response rate). From this set, we excluded: (1) incomplete responses, (2) responses that ware completed in a significantly shorter time than it took the test respondents (showing that respondents did not devote enough attention to the task), (3) responses that did not provide comparable answers to control questions (implying that respondents did not have adequate concentration throughout the task), (4) responses by 
Table 1: Measure validity and reliability indices (Crombach Alpha, AVE, CR)

\begin{tabular}{|l|c|c|c|}
\cline { 2 - 4 } \multicolumn{1}{l|}{} & $\begin{array}{c}\text { Crombach } \\
\text { Alpha }\end{array}$ & AVE & CR \\
\hline Cross-category competition & 0.692 & 0.480 & 0.699 \\
\hline Market orientation & 0.895 & 0.620 & 0.919 \\
\hline Market-driven approach & 0.828 & 0.661 & 0.886 \\
\hline Marketing department's capabilities & 0.788 & 0.703 & 0.876 \\
\hline Marketing department's integration with Agency & 0.737 & 0.583 & 0.841 \\
\hline Star Marketer & 0.971 & 0.921 & 0.979 \\
\hline Technology orientation & 0.900 & 0.770 & 0.930 \\
\hline Within-category competition & 0.697 & 0.499 & 0.795 \\
\hline
\end{tabular}

Note: All indicators are statistically significant. AVE is generally above 0,5 level, and CR above 0,7 level (see Hair, Black, Babin, \& Anderson, 2010). Market-driving approach is a formative scale.

individuals who are not marketing managers (or other function in charge of marketing), and (4) responses by incompetent respondents (Homburg \& Jensen, 2007). The result was 255 usable questionnaires (response rate of $16.21 \%$ ), which is comparable to other research targeting marketing managers as respondents (e.g. Verhoef \& Leeflang, 2009).

Where possible, we used existing measures from the literature to measure constructs, refining them to fit the purpose. Used measures exhibited adequate levels of validity and reliability.

\section{RESULTS AND DISCUSSION}

Firms in our sample operate equally in $\mathrm{B} 2 \mathrm{~B}$ and $\mathrm{B} 2 \mathrm{C}$ markets $(\mathrm{MD}=-.027$; $\mathrm{SD}=2.277 ; \mathrm{t}=-.193, \mathrm{p}=.847)$ with mean 3.97 on a 7-point scale $(1=$ "turnover totally from B2B", and 7 = "turnover totally from B2C"). They are somewhat more product-focused $(\mathrm{MD}=-.323 ; \mathrm{SD}=2.581 ; \mathrm{t}=-1.993 ; \mathrm{p}=.047)$ with a mean 3.68 on a 7-point scale ( $1=$ "turnover totally from goods", and 7 = "turnover totally from services"). Regarding size, most of the firms in our sample are "small", i.e. up to 50 employees (49.4\%), 19.2\% are medium sized (from 51 to 250 employees), $15.3 \%$ are large (251 to 1000 employees) and $16.1 \%$ are very large (above 1000 employees).

We used partial least squares structural equation modeling to evaluate the impact of the extent to which star marketers are engaged in a project on the choice of market strategy: market-driven vs. market-driving strategy. This method was chosen since the focus of the research was prediction (Hair, Hult, Ringle \& Sarstedt, 2017). Results indicate that star marketers are important drivers of company's engagement in market-driving contexts - above and beyond departmentlevel marketing capabilities, marketing department's integration with agency (as an external actor), organizational-level market-orientation, and market-level withincategory and cross-category competitive intensity. At the same time, star marketers do not add significant value for companies pursuing market-driven strategies. Marketdriven strategies are favored by companies that exhibit market orientation and face fierce within-category competition. 
Table 2: Measure discriminant validity indicator

(Heterotrait-Monotrait Ratio - HTMT)

\begin{tabular}{|c|c|}
\hline & HTMT \\
\hline Market orientation $->$ CrossCategory Competition & 0.092 \\
\hline Market-driven -> CrossCategory Competition & 0.092 \\
\hline Market-driven -> Market orientation & 0.875 \\
\hline MktDepartment - Capability -> CrossCategory Competition & 0.096 \\
\hline MktDepartment - Capability -> Market orientation & 0.549 \\
\hline MktDepartment - Capability -> Market-driven & 0.448 \\
\hline MktDepartment Integration with Agency $->$ CrossCategory Competition & 0.131 \\
\hline MktDepartment Integration with Agency -> Market orientation & 0.082 \\
\hline MktDepartment Integration with Agency -> Market-driven & 0.089 \\
\hline MktDepartment Integration with Agency -> MktDepartment - Capability & 0.068 \\
\hline Star Marketer -> CrossCategory Competition & 0.055 \\
\hline Star Marketer $->$ Market orientation & 0.053 \\
\hline Star Marketer -> Market-driven & 0.062 \\
\hline Star Marketer -> MktDepartment - Capability & 0.065 \\
\hline Star Marketer -> MktDepartment Integration with Agency & 0.017 \\
\hline Technology orientation -> CrossCategory Competition & 0.071 \\
\hline Technology orientation $->$ Market orientation & 0.598 \\
\hline Technology orientation $->$ Market-driven & 0.460 \\
\hline Technology orientation -> MktDepartment - Capability & 0.445 \\
\hline Technology orientation -> MktDepartment Integration with Agency & 0.163 \\
\hline Technology orientation $->$ Star Marketer & 0.039 \\
\hline WithinCategory Competition -> CrossCategory Competition & 0.571 \\
\hline WithinCategory Competition -> Market orientation & 0.126 \\
\hline WithinCategory Competition -> Market-driven & 0.154 \\
\hline WithinCategory Competition -> MktDepartment - Capability & 0.109 \\
\hline WithinCategory Competition -> MktDepartment Integration with Agency & 0.115 \\
\hline WithinCategory Competition -> Star Marketer & 0.084 \\
\hline WithinCategory Competition -> Technology orientation & 0.144 \\
\hline
\end{tabular}

Note: All values are below the required level of 0.9 (see Gold et al, 2001) 


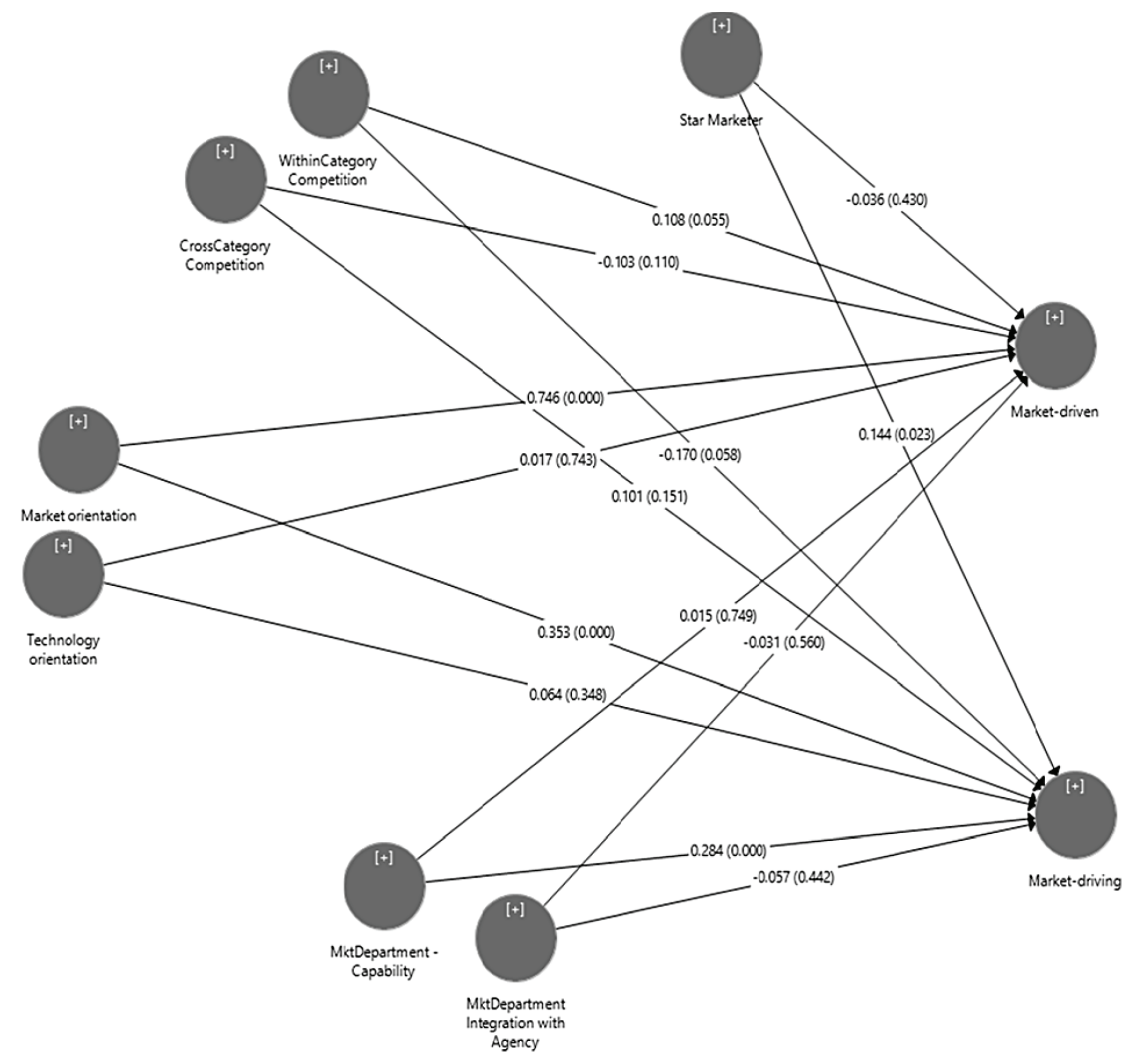

Figure 1: Structural model

Table 3: Partial Least Squares Structural Equation Modeling estimates

\begin{tabular}{|l|c|c|}
\cline { 2 - 3 } \multicolumn{1}{c|}{} & Market-driven approach & Market-driving approach \\
\hline Within-category competition & $0.108(0.056)^{* *}$ & $-0.170(0.089)^{* *}$ \\
Cross-category competition & $-0.103(0.064)$ & $0.101(0.070)$ \\
\hline Marketing department's capabilities & $0.015(0.048)$ & $0.284(0.066)^{* * *}$ \\
Marketing department's integration with Agency & $-0.031(0.053)^{* *}$ & $-0.057(0.074)^{* *}$ \\
\hline Market orientation & $0.746(0.05)^{* * *}$ & $0.353(0.059)^{* * *}$ \\
Technology orientation & $0.017(0.052)^{*}$ & $0.064(0.068)^{*}$ \\
\hline Star marketer & $-0.036(0.046)$ & $0.144(0.063)^{* *}$ \\
\hline $\mathrm{R}^{2}$ & $0.601(0.046)^{* * *}$ & $0.397(0.044)^{* * *}$ \\
\hline
\end{tabular}

Note: $* \mathrm{p}<.1 ; * * \mathrm{p}<.05 ; * * * \mathrm{p}<.01$. Table lists path coefficients with standard deviations in parenthesis. 
In markets characterized by strong within-category competition, firms tend to prefer market-driven strategies $(\beta=0.108$; $\mathrm{SD}=0.056$; sig $=0.055)$ and avoid marketdriving strategies $(\beta=-0.170 ; \mathrm{SD}=0.089$; sig=0.058). In such conditions, companies are having a hard time keeping up with the market changes, and have no resources left to consider or implement the more demanding and more long-term focused market-driving strategies. In markets characterized by strong cross-category competition, however, firms are marginally less likely to pursue marketdriven strategies $(\beta=-0.103 ; \mathrm{SD}=0.064$; $\operatorname{sig}=0.110$ ), as their category is rendered obsolete by competitors from outside their category.

At company level, a firm's market orientation tends to have a positive impact on both the extent to which the firm is able to deliver on market-driven strategies $(\beta=0.746$; $\mathrm{SD}=0.052$; sig $=0.000)$ and market-driving strategies $(\beta=0.353 ; \mathrm{SD}=0.059$; sig $=0.000)$. Therefore, firms that are market-oriented seem not to be "blinded" by markets, but rather tend to be both, driven by current markets and driving markets for the future to a greater extent than those companies which are not market oriented. On the other hand, technology orientation of companies does not have a significant impact neither on the extent to which a company will be marketdriven $(\beta=0.017 ; \mathrm{SD}=0.052 ;$ sig $=0.743)$ nor the extent to which that company will drive markets $(\beta=-0.064 ; \mathrm{SD}=0.068$; sig=0.348).

At the level of marketing department, a highly capable marketing department is paramount for companies to engage in market-driving strategies $(\beta=0.284$; $\mathrm{SD}=0.066$; $\operatorname{sig}=0.000)$. However, capabilities are not crucial for companies that engage in simpler market-driven strategies $(\beta=0.015$; $\mathrm{SD}=0.048$; sig=0.749). Market-driven strategies require marketing departments that are able to understand and respond to market information, while market-driving strategies put greater requirements on marketing departments since they need to understand and change markets. Integration of marketing departments with marketing agencies did not show a significant impact either on the extent to which a firm will pursue market-driven strategy $(\beta=-0.031 ; \mathrm{SD}=0.053$; sig $=0.560)$ or the extent to which a firm will pursue market-driving strategies $(\beta=-0.057$; $\mathrm{SD}=0.074 ; \quad \operatorname{sig}=0.442)$. The insignificant impact of integration with the marketing agency implies that marketing strategy is primarily determined by the company, while the marketing agency is more involved with strategy execution (thus having no effect on the extent to which certain strategy will be employed).

Lastly, the role of star marketer is evident for firms pursuing market-driving strategies $(\beta=0.144 ; \mathrm{SD}=0.063 ;$ sig $=0.023)$ while exhibiting insignificant impact on the marketdriven strategy implementation $(\beta=-0.036$; $\mathrm{SD}=0.046 ;$ sig=0.430). Therefore, while organizations exhibiting market-orientation are likely to deliver market-driven strategies, for them to implement market-driving strategies it is crucial to have a highly capable marketing department, but also involve star marketers. Star marketers are therefore able to more easily envision opportunities of market-driving strategies and are more likely to pursue such audacious strategies.

\section{CONCLUDING REMARKS}

Market driving strategy requires a star marketer on board (H1 accepted). Having star marketers provides the company with great knowledge breadth and daring individual, therefore favoring market-driving strategies. A star marketer is so highly important that he/she reduces the importance 
of integration with marketing agency and department's capabilities. On the other hand, for firms pursuing market driven strategies, having star marketers does not add value (H2 accepted). Moreover, in that case, having a star marketer presents only an "unnecessary cost" adding limited value to firm's market-driven strategies, and the firm might be better off employing non-star marketers equipped with an information processing unit. In order to justify their salaries, star marketers should have a strategic role of managing markets through market driving strategies, rather than being mere analyzers of market information (Levitt, 1962).

In order to test the robustness of these results, we also conducted multiple regression

\section{References}

1. Allen, T., \& Cohen, S. I. (1969). Information flow in R\&D laboratories. $A d$ ministrative Science Quart, 14, 12-19.

2. Amabile, T. M., Conti, R., Coon, H., Lazenby, J., \& Herron, M. (1996). Assessing the work environment for creativity. Academy of Management Journal, 39(5), 1154-1184.

3. Atuahene-Gima, K. (2005, October). Resolving the capability-rigidity paradox in new product innovation. Journal of Marketing, 69, 61-83.

4. Bennett, R. C., \& Cooper, R. G. (1979, June). Beyond the marketing concept. Business Horizons, 22, 76-83.

5. Carpenter, G. S., \& Nakamoto, K. (1989). Consumer preference formation and pioneering advantage. Journal of Marketing Research, 26, 285-298.

6. Carpenter, G. S., \& Nakamoto, K. (1994). Reflections on "Consumer preference formation and pioneering advantage". 31, pp. 570-573. analyses, arriving to the same conclusions regarding the importance of star marketers for market-driving strategies. While this research points to an important new variable (stemming from heterogeneity of the workforce), further research should focus on understanding the role of the star marketer in different stages of strategy development and execution, in order to best optimize their time and effort in market-driving projects. Without star marketers in teams, organizations are likely to be driven by markets (even possibly "blinded" by markets) and their strategies are likely to converge. Star marketers enable companies to continuously restructure existing markets and preferences, as well as to persistently create new markets and market opportunities.

7. Carpenter, G. S., \& Nakamoto, K. (1994a, November). Reflections on "Consumer preference formation and pioneering advantage". 31, pp. 570-573.

8. Chandy, R., \& Tellis, G. (1998, November). Organizing for radical product innovation: The overlooked role of willingness to cannibalize. Journal of Marketing Research, 35, 474-487.

9. Christensen, C. M., \& Bower, J. L. (1996). Customer power, strategic investment, and the failure of leading firms. Strategic Management Journal, 17(1), 197-218.

10. De Luca, L. M., \& Atuahene-Gima, K. (2007, January). Market knowledge dimensions and cross-functional collaboration: Examining the different routes to product innovation performance. Journal of Marketing, 71(1), 95-112.

11. Deshpandé, R., \& Farley, J. U. (1999). Executive insights: Corporate culture and market orientation: Comparing Indian and Japanese firms. Journal of International Marketing, 7(4), 111-127. 
12. Ernst, H., Laptien, C., \& Vitt, J. (2000). Inventors are not alike: The distribution of patenting output among industrial R\&D personnel. IEEE Transactions on Engineering Management, 47, 184-199.

13. Felin, T., \& Hesterly, W. S. (2007). The knowledge-based view, nested heterogeneity, and the new value creation: Philosophical considerations on the locus of knowledge. Academy of Management Review, 32(1), 195-218.

14. Gatignon, H., \& Xuereb, J.-M. (1997, February). Strategic orientation of the firm and new product performance. Journal of Marketing Research, 34(1), 77-90.

15. Guenzi, P., \& Troilo, G. (2006). Developing marketing capabilities for customer value creation through marketing-sales integration. Industrial Marketing Management, 35(8), 974-988.

16. Hair, J. F., Black, W. C., Babin, B. J., \& Anderson, R. E. (2010). Multivariate Data Analysis. Upper Saddle River: Pearson.

17. Hargadon, A., \& Sutton, R. I. (1997). Technology brokering and innovation in a product development firm. Administrative Science Quarterly, 42(4), 716749.

18. Heyes, R. H., \& Abernathy, W. J. (1980, July-August). Managing our way to economic decline. Harvard Business Review, 58, 67-77.

19. Homburg, C., \& Jensen, O. (2007, July). The thought worlds of marketing and sales: Which differences make a difference. Journal of Marketing, 71, 124-142.

20. Jaworski, B., Kohli, A. K., \& Sahay, A. (2000). Market-driven versus driving markets. Journal of the Academy of Marketing Science, 28(1), 45-54.
21. Kogut, B., \& Zander, U. (1992). Knowledge of the firm, combinative capabilities, and the replication of technology. Organization Science, 3(3), 383-397.

22. Kohli, A. K., \& Jaworski, B. J. (1990, April). Market orientation: The construct, research propositions, and managerial implications. Journal of Marketing, 54, 1-18.

23. Kumar, N. (1997). The revolution in retailing: From market driven to market driving. Long Range Planning, 30(6), 830-835.

24. Kumar, N., Scheer, L., \& Kotler, P. (2000). From market driven to market driving. European Management Journal, 18(2), 129-142.

25. Leiponen, A., \& Helfat, C. E. (2010). Innovation objectives, knowledge sources, and the benefits of breadth. Strategic Management Journal, 31(2), 224-236.

26. Levinthal, D. A., \& March, J. G. (1993). The myopia of learning. Strategic Management Journal, 14, 95-112.

27. Levitt, T. (1962). Innovation in marketing: New perspectives for profit and growth. New York: McGraw-Hill.

28. Lotka, A. (1926). The frequency distribution of scientific productivity. Journal of Washington Academy of Science, 16, 317-323.

29. McDermott, C. M., \& O'Connor, G. C. (2002). Managing radical innovation: An overview of emergent strategy issues. Journal of Product Innovation Management, 19(6), 424-438.

30. Narver, J. C., \& Slater, S. F. (1990, October). The effect of a market orientation on business profitability. Journal of Marketing, 54, 20-35.

31. Narver, J. C., Slater, S. F., \& MacLachlan, D. L. (2004, September). Respon- 
sive and proactive market orientation and new-product success. Journal of Product Innovation Management, 21(5), 334-347.

32. Prabhu, J. C., Chandy, R. K., \& Ellis, M. E. (2005). The impact of acquisition on innovation: Poison pill, placebo or tonic? Jourrnal of Marketing, 69(1), 114-130.

33. Reed, R., \& DeFillippi, R. J. (1990). Causal ambiguity, barriers to imitation, and sustainable competitive advantage. Academy of Management Review, 15(1), 88-102.

34. Roberts, J. H., \& Lattin, J. M. (1991, November). Development and testing of a model of consideration set composition. Journal of Marketing Research, 28, 429-440.

35. Rothaermel, F. T., \& Hess, A. M. (2007). Building dynamic capabilities: Innovation driven by individual-, firm-, and network-level effects. Organization Science, 18(6), 898-921.

36. Russell, G. J., Ratneshwar, S., Shocker, A. D., Bell, D., Bodapati, A., Degeratu, A., . . . Shankar, V. H. (1999). Multiple category decision-making: Review and synthesis. Marketing Letters, 10(3), 319-332.

37. Shocker, A. D., Bayus, B. L., \& Kim, N. (2004, January). Product complements and substitutes in the real world: The relevance of "other products". Journal of Marketing, 68, 28-40.

38. Soberman, D. A. (2009). Marketing agencies, media experts and sales agents: Helping competitive firms improve the effectiveness of marketing. International Journal of Research in Marketing, 26(1), 21-33.

39. Tushman, M. L. (1977). Special boundary roles in the innovation process. Administrative Science Quart, 22, 587-605.

40. Verhoef, P. C., \& Leeflang, P. S. (2009, March). Understanding the marketing department's influence within the firm. Journal of Marketing, 73, 14-37.

41. Zhou, K. Z., Yim, C. K., \& Tse, D. K. (2005, April). The effects of strategic orientations on technology- and marketbased breakthrough innovations. Journal of Marketing, 69, 42-60.

42. Zucker, L. G., \& Darby, M. R. (1997). Individual action and the demand for institutions: Star scientists and institutional transformation. American Behavioral Scientist, 40(4), 502-513.

43. Zucker, L. G., Darby, M. R., \& Brewer, M. B. (1998). Intellectual human capital and the birth of U.S. biotechnology enterprises. American Economic Review, 88(1), 290-306.

44. Zucker, L., \& Darby, M. (1998). Entrepreneurs, star scientists and biotechnology. Retrieved from NBER Reporter Online: http://www.nber.org/reporter/ fall98/zucker-darby_fall98.html

45. Zuckerman, E. W., \& Phillips, D. (2001). Middle-status conformity: Theoretical restatement and empirical demonstration in two markets. American Journal of Sociology, 107, 379-429. 


\section{UTJECAJ „MARKETINŠKIH ZVIJEZDA“ NA IZBOR MARKETINŠKE STRATEGIJE}

\section{Sažetak}

U ovom se radu autori fokusiraju na ulogu "marketinških zvijezda" u provedbi tržišno vođene strategije, nasuprot strategije vođenja tržišta. Rezultati ukazuju da su strategije vođenja te one vođene tržištem dva pristupa, koja se mogu primijeniti u tržišno orijentiranim poduzećima. Pritom „marketinške zvijezde" imaju čvrst utjecaj na strategiju vođenja tržišta, odnosno nemaju nikakvog jasnijeg utjecaja na strate- giju vođenu tržištem. Ukratko rečeno, dok su "marketinške zvijezde" vrlo značajne za strategiju vođenja tržišta $i$ dugoročni uspjeh, one predstavljaju nepotreban trošak i ne stvaraju vrijednost za poduzeća, usredotočena na strategije vođene tržištem i kratkoročne rezultate.

Ključne riječi: strategija vođenja tržišta, strategija vođena tržištem, ,,marketinške zvijezde", tržišna orijentacija 
